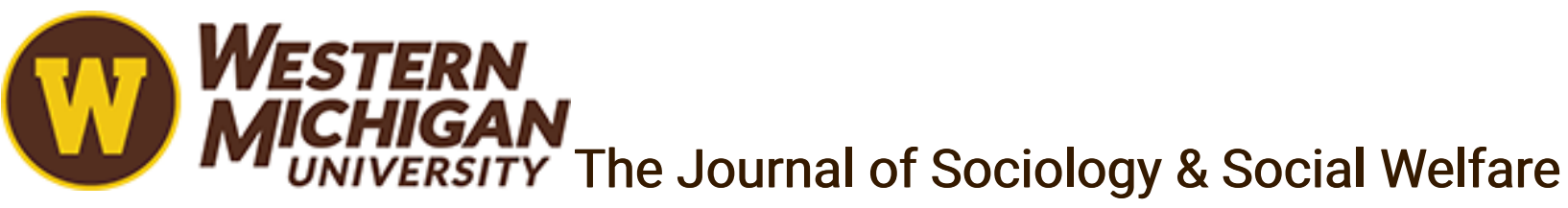

Volume 7

Issue 3 May

Article 7

May 1980

\title{
Mission Neighborhood Health Center: A Case Study of the \\ Department of Health Education and Welfare as a Counterinsurgency Agency
}

Thomas S. Bodenheimer

Institute for the Study of Labor and Economic Crisis

Follow this and additional works at: https://scholarworks.wmich.edu/jssw

Part of the Health Policy Commons, Social Welfare Commons, and the Social Work Commons

Recommended Citation

Bodenheimer, Thomas S. (1980) "Mission Neighborhood Health Center: A Case Study of the Department of Health Education and Welfare as a Counterinsurgency Agency," The Journal of Sociology \& Social Welfare: Vol. 7 : Iss. 3 , Article 7.

Available at: https://scholarworks.wmich.edu/jssw/vol7/iss3/7

This Article is brought to you by the Western Michigan University School of Social Work. For more information, please contactwmu-scholarworks@wmich.edu.

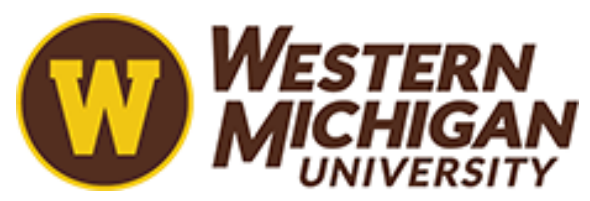


390

MISSION NEIGHBORHOOD HEALTH CENTER: A CASE STUDY OF THE DEPARTMENT OF HEALTH EDUCATION AND WELFARE AS A COUNTERINSURGENCY AGENCY

Thomas S. Bodenheimer, M.D., M.P.H. Institute for the Study of Labor and Economic Crisis*

In the $1960^{\circ} \mathrm{s}$, working class communities all over the country, particularly minority inner city neighborhoods, exploded in violent anger. The federal government responded with a pacification or cooling-out program: the War on Poverty. The war on Poverty provided federal funds to bring a few programs into the community, to create a few jobs, and to buy off working class leaders who were a threat to those in power. In the course of this program of counterinsurgency, the War on Poverty took over a slogan of the $1960^{\circ} \mathrm{s}$, "community control," and turned it into its opposite; rather than control by the community, "community control" came to mean control over the working class majority of the community.

One of the War on Poverty's important programs was the neighborhood health center program to provide ambulatory health care to low income people. This program, initially slated to reach $25 \mathrm{milli}$ on people through 1,000 health centers, was scaled down to 125 centers serving only 1.5 million people. The standard view of the neighborhood health center program holds that its

\footnotetext{
* The Institute for the Study of Labor and Economic Crisis was requested by Mission Neighborhood Health Center patients to assist in their fight for democratic elections and decent health care. This paper reflects the Institute's understanding gained through active participation in this struggle. The analysis put forth in the paper was developed by Marlene Dixon, Ph.D., Research Director at the Institute. Any shortcomings in the paper are entirely the responsibility of the author.

This paper was first presented at the Society for the Study of Social Problems, August 1979. Please direct all communications to the author. Institute for the study of Labor and Economic Crisis, 131 Townsend St., San Francisco, California 94107.
} 
aims were 1) to bring high quality health care to people previously denied such care, 2) to provide employment opportunities and training to neighborhood residents, and 3) to allow community members to participate in the governance of the health centers (Davis and Schoen, 1978). A more realistic view sees the neighborhood health center program as a means to control, rather than to assist. minority working class populations. This paper takes the example of one neighborhood health center. Mission Neighborhood Health Center in San Francisco, to show how federal counterinsurgency works in the 1970's and to expose the class character of "community control."

The Exploitation of Patients at Mission Neighborhood Health Center

Mission Neighborhood Health Center (MNHC) was opened in the late $1960^{\circ} \mathrm{s}$ by the Office of Economic Opportunity. the War on Poverty's central agency, to provide health services to San Francisco's Mission District. More recently, MNHC has been funded by the federal Department of Health Education and Welfare (HEW), which took over many of the War on Poverty programs. MNHC is the only fully bilingual health service available to the tens of thousands of non-English speaking Latino people of San Francisco.

During its first years, MNHC was run by a medical entrepreneur who used MNHC funds to help develop his own private medical office building nearby (Hartman and Feshbach, 1974). In 1975, a months-long community struggle forced HEW to give the MNHC grant to the Mission Area Health Associates (MAHA), a new community group with a board of trustees whose majority was supposed to be elected by the health center's own patients. MAHA's victory was considered to be a triumph for community control at MNHC.

In 1977, a small clique of Latino youths gained control over the MAHA board of trustees. This clique ran a network of Mission District poverty agencies, mainly concerned with youth programs, including the Real Alternatives Program, Centro de Cambio and Mission Community Legal Defense. At MNHC they named another member of their clique to the $\$ 25,000$ a year job as health center administrator, though their friend had no experience administering a 
health care institution.

By 1979 the health center was in shambles and its patients were up in arms. Patients were forced to wait in long lines to pay fees before being cared for. For several months, patients who had outstanding bills were not allowed to receive medical services until they settled their bills. Many patients were receiving incorrect bills for services they had never gotten or had already paid for. A number of competent health professionals and employees were terminated, sometimes leaving patients without their health care provider from one day to the next. The board had purchased an extremely expensive and poorly programmed computer that caused patients to wait an average of $13 / 4$ hours to register at the health center. Transportation services for elderly patients were reduced while money was wasted on excess administrative salaries. The health center's financial deficit topped $\$ 200,000$.

Worst of all, the clique running the board refused to hold the yearly elections required by their own by-laws. As the San Francisco Examiner's columnist Guy Wright (1979a) put it.

Board members whose terms expired more than a year ago still cling to their seats, adopting budgets, handing out raises, firing anyone who objects -- and appointing friends to fill vacancies when anyone resigns from the board.

HEN, which has the responsibility of administering the MNHC grant, knew of and ignored or encouraged the mismanagement at the health center. HEW allowed the health center's administrative costs to increase from $21 \%$ to $28 \%$ of the budget (U.S. Department of HEN, 1979a), though HEW sugges ts that such costs not exceed $20 \%$. HEW approved the purchase of the computer that was later investigated by the FBI for possible fraudu-

* Documentation for the facts presented in this paragraph come from numerous MNHC memos and from the author's own experience of being employed at MNHC for $3 \frac{1}{2}$ years before his firing in June 1979. 
lent bidding practices and kickbacks (U.S. Department of HEW, 1979b). HEW allowed the clinic's board members to continue in office beyond their legal terms of office without demanding immediate elections, and HEW repeatedly backed this board as the health center's legitimate governing body.

\section{The Health Center's Patients Fight Back}

In 1979, as a result of community pressure, new elections finally began. But in May, the clique controlling the board disqualified a number of the candidates in the election. Board members and their supporters physically and verbally intimidated volunteers attempting to help get the election underway. A fight took place at the clinic between board members and volunteers, and the election never took place.

Thereupon, 70 patients of the health center sued the board and won a June 8 agreement that the elections must start immediately, under the supervision of a neutral third party. Stili, no action was taken to hold the elections. With the help of the Rebel Worker Organization and the Grass Roots Alliance, worker and community organizations who had been asked to get involved, over 100 patients formed themselves into the Patients Defense Association. They arrived en masse at the June 20 MAHA board meeting to demand decisive patient representation in the running of the clinic. They were denied.

The Association, many of whose members were already refusing to use clinic services, voted to formally boycott the clinic. For four weeks, the patients picketed the clinic, marching, educating and persuading. Hundreds of patients honored the boycott, going without health care or using alternative health services set up by the Rebel Worker Organization. Patients sent hundreds of letters and petition signatures to their elected representatives in washington. By the end of the boycott, the Patients Defense Association had grown to 800 members.

During the boycott, physical intimidation showed itself again. One Patients Defense Association activist had sugar poured into the gas tank of her car; another had her car windshield broken; and yet another had objects thrown at the windows of her home. Gangs of youths 
threateningly drove around the picket line, which was largely made up of women and children.

Finally, the Regional Health Administrator of HEW, Dr. Sheridan Weinstein, met with the Patients Defense Association and agreed to guarantee a fair election procedure. But at the same time that $\mathrm{Dr}$. Weinstein was negotiating with the Association, his office was encouraging and financing a lawsuit against the very organizations (the Grass Roots Alliance, Rebel Worker Organization, and the Institute for the Study of Labor and Economic Crisis) who were assisting the patients in their struggle for democratic elections and decent health care. This lawsuit, brought by the clique controlling the MAHA board, asked for $\$ 1$ million in damages for libel and conspiracy.

HEW's promise to guarantee fair elections had little substance. The Patients Defense Association's lawyers were forced to go into court time and time again, and only after obtaining ten court orders did the elections finally take place. The MAHA board and its lawyers, using $\mathrm{HEW}$ funds to finance one after another courtroom maneuver, delayed the elections in every way possible, including resisting a judge's order. HEW was clearly supporting the MAHA board and thereby keeping the organized working class patients from participating in the election. Only another massive letter writing appeal to government officials, combined with victory after victory in court, brought about the elections. On Cctober 9, after an intense 5 month struggle, the elections were concluded. All $\mathrm{Pa}-$ tients Defense Association candidates won seats on the new MAHA board by overwhelming majorities.

HEW again moved to block organized working class power over the clinic. After reducing the clinic's budget, HEW laid down strict conditions to the new board requiring immediate crippling layoffs of clinic employees and cutbacks in services. Failure to meet these conditions would result in the replacement of the new MAHA board by another community agency. The new board, with its patient majority, is faced with running a clinic left in financial shambles by the old board and beseiged by HEN cutbacks and threats to take the grant away. As columnist Guy Wright (1979b) put it,

HEw, which gave the old board extra money because it was doing such a poor job, has 
cut back on funding for the new board. which must clean up the mess.

\section{Analysis: HEN as Counterinsurgency}

Historically, the federal government has spent money for welfare and social service programs only at times of mass insurgency by the working class (Piven and Cloward, 1971). In the 1930's the government enacted social security, unemployment and welfare programs in response to the demonstrations and protests of millions of people, many organized by the growing Communist Party. The $1950^{\prime} \mathrm{s}$, with little organized working class unrest, produced almost no new social programs. But the $1960^{\circ} \mathrm{s}$, with its civil rights movement and urban rebellions, brought a massive increase in welfare expenditures, new health programs including Medicare, Medicaid and neighborhood health centers, educational programs such as Headstart, and "community action" and legal services programs to put some pressure on local and state governments. In fact, many of the War on Poverty programs were targeted into areas of actual or potential urban rebellion.

These federal moneys, then, served as a massive domestic counterinsurgency effort, designed to stop any effective working class protest that could take root and threaten the stability of the existing capitalist order. Domestic counterinsurgency works by 1) channeling money to programs which minimally alleviate the worst horrors of life in minority working class communities but which principally provide charity and create dependency on government funds; and 2) funneling the money through agencies that hire working class leaders and buy them off with $\$ 20,000$ a year positions and with control over other jobs in the community. Those who would not be bought off in this manner were frequently assassinated or imprisoned, for example, leaders of the Black Panthers. Those who were coopted became known to many as poverty pimps, and formed a new stratum of society, a stratum created by the needs of the state to control the working class in minority noighborhoods (Rebel Worker Newsjournal, 1979). The poverty pimps became the managers of the counterinsurgency programs, and as such gained control over aspects of the lives of the working class majority in their communities. Their 
control was termed "community control" because the poverty pimps came from the community. In this sense, "community control" has come to mean control over the working class community. The clique that ran the MAHA board from 1977 to 1979 is a clear example of this stratum of poverty pimps.

\section{The Poverty Pimps: a Lumpen Petty Bourgeoisie}

Using the terminology of Marxist class analysis, the poverty pimps are a new stratum of the lower rungs of the bourgeois class. Our society is made up of two antagonistic classes, the bourgeoisie (capitalist

class) and the proletariat (working class) (Dixon, 1979). The capitalist class owns and controls the vast majority of the wealth -- the land, the factories, the oil and natural resources. The working class is forced to work for the capitalist class in order to survive, and those unable to work become dependent upon and controlled by government programs such as social security, unemployment compensation, disability and such services as those offered by neighborhood health centers.

The lower strata of the bourgeois class are the petty (small) bourgeoisie, most of whom today are employed by capital or by the state as managers and professionals. Their function is to carry out the orders of the capitalists in controlling and commanding the day-to-day activities of the working class (Braverman, 1974). In the factory, this function is performed by the planners, managers and foremen; in the welfare system it is performed by the social workers. The petty bourgeoisie does not in itself possess control over the country's resources but, in return for financial rewards, it serves as a transmission belt of control between the bourgeoisie and the working class.

The stratum of the petty bourgeoisie that we call the poverty pimps is a new stratum, created by the counterinsurgency programs of the federal government. Their purpose is to manage these programs for the benefit of the government and thereby to pacify and control the working class on behalf of the bourgeoisie. Many poverty pimps may have taken their poverty agency positions with the best of intentions. But any desires to serve the community are snuffed out by the reality that they function as part of a state apparatus designed to rule and 
control their communities (Rebel Worker Newsjournal, 1979). The poverty pimps have a stake in maintaining the status quo in order to keep their own jobs. They may engage in petty (or big) rip-offs of public funds, and they create well-paying jobs for their friends and themselves to preserve and expand their positions and control. They come to identify with the government funding agency against their own people.

When the poverty funds begin to shrink, the poverty pimps may resort to any means -- including using their own gangs -- to keep their jobs and their control and to prevent themselves from being forced back into the working class whence they came. This stratum of poverty pimps is actually a lumpen petty bourgeoisie*. a stratum of parasites created by the War on Poverty. supported by taxpayers' money.

To conceal their true purpose from the working class that they exploit, those poverty pimps who are from minority communities may use the ideology of nationalism; for example.

How can you criticize me, I'm Raza. We are united by the racism we experience, so you should support me. It doesn't matter that I make $\$ 30,000$ a year while you and your family are on welfare. We are the same because my name is Gomez too (Martinez, 1979).

This kind of nationalism is a trick against the working class. It takes people's hatred of racism and twists it into a weapon against them (Martinez, 1979). And many white liberal and progressive people glorify the poverty pimps, calling them "The Community," when actually they are a tiny portion of the community that exploits the working class majority.

Domestic counterinsurgency and its creation of a lumpen petty bourgeoisie is in essence no different

* According to Marx, the lumpen proletariat are the petty criminals, pimps, small drug pushers -- the poor who steal from the poor and exploit the poor, whose role in history is as a "bribed tool of reactionary intrigue.' 
than the international counterinsurgency which motivated such programs as the Alliance for Progress in the $1960^{\prime} \mathrm{s}$. The Alliance for Progress infused money into Latin America to pacify growing anti-American social movements. ${ }^{*}$ It also created and strengthened a stratum of compradors (people who sold out the interests of their country for personal gain) similar to the poverty pimps, to administer the Alliance for Progress money and to control the population (for descriptions of world class formation, see Dixon. 1978; Jonas and Dixon, 1979). In its arsenal of counterinsurgency techniques, the Alliance for Progress utilized both the carrot and the stick: the food, agricultural and housing programs; and the repressive military and police apparatus.

HEW domestic counterinsurgency also utilizes both the carrot and the stick. The carrot is the charity of giving money to tranquilize the people and buy off their leaders; to make people depend on welfare checks, food stamps and neighborhood health centers; and thereby to prevent their organizing to really change their situation in society. The stick is to take away these charities if people cause trouble, a stick which is used to control both the poverty pimps and the working class. "Step out of line and you'll lose your little empire." the Feds tell the pimps. "Step out of line and you'll lose your food stamps, your clinics or your Headstart programs," the pimps tell the people (Rebel Worker Newsjournal, 1979).

\section{Counterinsurgency at Mission Neighborhood Health Center}

At MNHC, HEW counterinsurgency has shown itself as unwavering support for the poverty pimps, the small clique that controlled the MAHA board, against the

\footnotetext{
* The Alliance for Progress also served to create demand for U.S. products, which is an example of state capitalism -- taxpayers' money funneled into corporate profits. HEW funding of health programs is also state capitalist as well as counterinsurgent, but that is not the subject of this paper.
} 
organized working class patients. HEW knew for months that the board was violating its own by-laws by not holding elections, yet HEW continued to back them. In particular, when the Patients Defense Association, Rebel Worker Organization and Grass Roots Alliance began to work together to demand fair elections, HEW financed and encouraged the board's legal maneuvers to sabotage the elections and to sue the patients' supporters (Puga v.Hernandez, 1979). HEW attempted to discourage the patients and make them give up, and on several occasions blamed the patients for causing the problems at the clinic, problems for which HEW was actually responsible. And in encouraging the lawsuit against the patients' supporters, HEW was attempting to silence its own critics, showing no regard for freedom of speech and the right of responsible criticism.

The clique running the MAHA board acted in classic lumpen petty bourgeois fashion, with its financial exploitation of the working class -- making the patients pay increased clinic fees (often in cash) to support the high administrative salaries voted by the board for their friends. The clique did everything in its power to keep the working class from taking away its control over the clinic. And the clique attempted to disorganize the patients by warning that further protest would cause HEW to close down the clinic ("Step out of line and you'll lose your clinic.")

Now that the clique has been removed and a new patient-dominated board has been elected. HEW is pulling out an old favorite in its bag of counterinsurgency tricks: if you don't do what we say, we'll give the grant to someone else ("Step out of line and you'il lose your little empire.") In its October 3. 1979 grant award, HEW places 20 conditions on the new board, in particular the requirement for immediate substantial cutbacks in services. If the new board fails to meet these anti-patient conditions. HEW will look for another organization to run the clinic (U.S. Department of HEW, 1979c). In that way, HEW is trying to repeat the cycle: trying to turn a new group of working class people into a new clique of poverty pimps, who take the side of HEW rather than of the patients whom they were elected to represent. Using the carrot (control over jobs and money) and the stick (do what 
we want or we'll give the grant to someone else), HEW will forever attempt to coopt and control the struggles of working class people for a voice in the decisions that affect their lives.

\section{The Fight for True Patient Representation}

The struggle for elections at MNHC was not a struggle to replace one set of poverty pimps with another. It was about democracy, about a voice for the majority of working class people in our country who have always been disenfranchised and ignored. The patients who won the recent MNHC election didn't seek to be on the board as unaccountable individuals. They were chosen as representatives of the 800 -member $\mathrm{Pa}$ tients Defense Association, and they pledged to represent the interests of the Association, of the patients of the health center, and not just of themselves.

In a statement made during the MNHC boycott, the Patients Defense Association spoke:

For too long, patient representation has been a sham at the health center. One set of so-called "community leaders" after another have gained control, claiming the support of the community that they jid not have. Until now, patients have never organized for the principle of true patient representation. If patients are not organized, these small groups of "leaders" can continue to get in power and refuse to listen to us. We are trying to do something that we haven't seen done before: get patient representatives who are accountable to a democratic organization of hundreds of patients (Patients Defense Association, 1979).

Whether true patient representation can actually be achieved in the case of MNHC remains to be seen. The counterinsurgent pressure from HEW is strong and must be resisted every day. What counts is whether the new board will consistently fight for the interests of the patients and against the control imposed by HEW. 


\section{References}

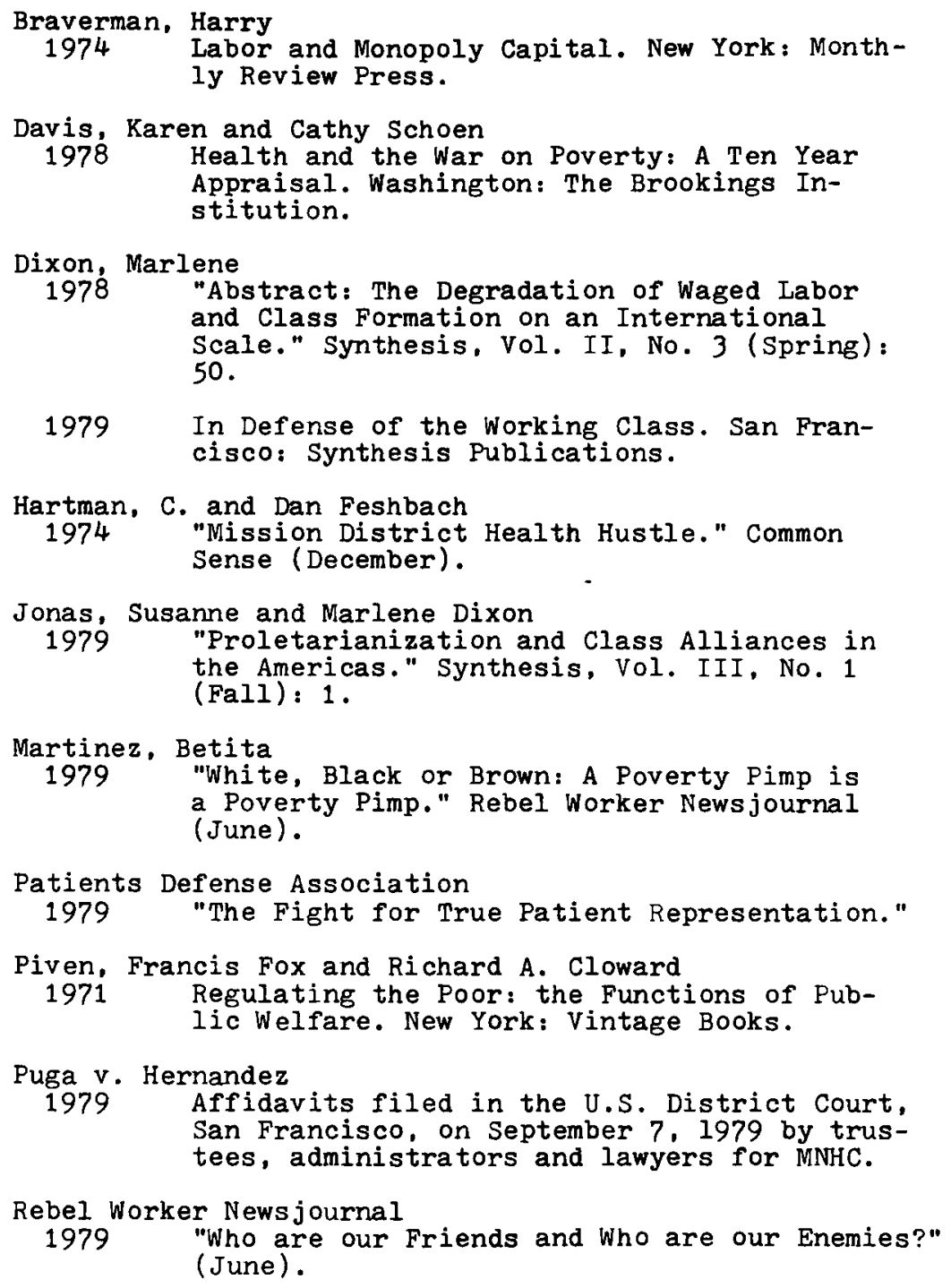

1979 In Defense of the Working Class. San Francisco: Synthesis Publications.

Hartman, C. and Dan Feshbach

1974 "Mission District Health Hustle." Common Sense (December).

Jonas, Susanne and Marlene Dixon

1979 "Proletarianization and Class Alliances in the Americas." Synthesis, Vol. III, No. 1 (Fall): 1 .

Martinez, Betita

1979 "White, Black or Brown: A Poverty Pimp is a Poverty Pimp." Rebel Worker Newsjournal (June).

Patients Defense Association

1979 "The Fight for True Patient Representation."

Piven, Francis Fox and Richard A. Cloward

1971 Regulating the Poor: the Functions of Public Welfare. New York: Vintage Books.

Puga v. Hernandez

1979 Affidavits filed in the U.S. District Court, San Francisco, on September 7, 1979 by trustees, administrators and lawyers for MNHC.

Rebel Worker News journal

1979 "Who are our Friends and Who are our Enemies?" (June). 
U.S. Department of Health Education and Welfare 1979a Program Indicators.

1979b Memo from Region IX HEW office to San Francisco office of the FBI.

1979c October 3 Notice of Grant Award to MNHC.

Wright, Guy

1979a "A Sick Health Center." San Francisco Examiner (August 1).

1979b "Health Center Future." San Francisco Examiner (November 22). 